\title{
A Review on Productivity and its Effect in Industrial Manufacturing Rajesh Shankar Priya ${ }^{1^{*}}$ \& Vincent Aroulmoji ${ }^{2}$
}

\author{
${ }^{1}$ Teesside University, Middlesbrough, United Kingdom \\ ${ }^{2}$ Center for Research \& Development, Mahendra Engineering College (Autonomous), \\ Salem-Tiruchengode Highway, Namakkal, 637503, Tamil Nadu, India
}

\begin{abstract}
Productivity is a widely discussed topic in companies and by leaders, as productivity is directly linked to the GDP growth and the quality of life. However, research suggests that Productivity is one of the most ambiguous terminologies that exist. Even though, productivity is closely related to profitability, efficiency and effectiveness, all these terminologies are used in a different context. In this review, the author will clearly highlight the differences in these terminologies and provide insights in the context of enhancing performance. In the United Kingdom, manufacturing productivity is on par with Germany however, in other sectors there is a downfall. This review is focused on providing fundamental knowledge on Productivity and why it is important for all sectors?
\end{abstract}

KEYWORDS: Productivity, Performance, Profitability, Efficiency, Effectiveness, Competitive Priorities, Manufacturing, United Kingdom, Automotive.

https://doi.org/10.29294/IJASE.6.4.2020.1490-1499

(C) 2020 Mahendrapublications.com, All rights reserved

\section{INTRODUCTION}

The terminology productivity is a triumph card for politicians and managers but the term itself is often confused with the term production [1]. Productivity is often projected in correlation with production, misleading to a concept of increased production linked to increased productivity. For over two centuries, productivity is stated as a simple relationship between output and input and it has remained a proven variable in economics [1-6]. The ratio of productivity is calculated by the relation of output to input. The output can be expressed in terms of unit or volume, while the input ratio can be manpower or machinery involved material resources and in a fiscal format. In simple terms, a 37 hour / week working contract given to an employee in an enterprise to fulfill a particular set of task, when fulfilled by an employer in 37 hours in a week has a productivity index of 1.0. This simple but significant relationship between output and input of resources affects a company's competitiveness on the whole, if more input yields less output [7-10]. In economic terms, productivity is classified as Labor Productivity and Total factor productivity. The definition of labor productivity being defined as total labor output divided by the labor inputs [11]. This measure of productivity gives highlights the company's performance of its labor force in relation to its efficient output creation. The volume measure of output indicates the task performed by the work force, The output is measured either by gross domestic product
(GDP) or gross value added (GVA) [12].The measure of input indicates the overhead factors of time, effort and skills of the workforce. The input measure is the most influential parameter in measuring the labor productivity. Labor input is measured either by the total number of hours worked of all persons employed or total employee [12]. Most of the research literature claims labor productivity as the most outcome oriented variable in human resource management. Total Factor Productivity (TFV) corresponds to an output which is related to a different set of combined inputs used in production, such as labor, capital, energy sources, materials, inventories, land or infrastructure [13]. The growth derived from the total factor productivity index is usually calculated by subtracting the contribution of growth in capital-labor ratio from labor productivity growth [14]. The total factor productivity increases when the efficiency of the system is incremented by efficient use of input variables [15]. However, It is impossible to measure total factor productivity directly [16].Instead, it is a residual which accounts for effects on total output not caused by inputs.The Cobb-Douglas function illustrates the total productivity index in this specific format:

$$
\mathrm{Y}=\mathrm{c} \cdot \mathrm{L}^{\mathrm{a}} \cdot \mathrm{K}^{\mathrm{b}}
$$

Equation 1: Cobb-Douglas Production function

${ }^{*}$ Corresponding Author: R.ShankarPriya@tees.ac.uk

Received: 16.02 .2020

Accepted: 21.03.2020

Published on: 18.04 .2020 
According to the production function, the output $\mathrm{Y}$ is equal to the Total Factor productivity (C) multiplied to labor (L) and capital (K) where "a" and "b" are the output elasticity of Labor and Capital. The function demonstrates that any increase in input value namely capital or labor create an automatic increase in the output value but it is efficient feeding of input values that finally determines the amount of output produced [17]. The total productivity depends on various constraints including the amount of labor, the innovation pattern of a particular organization and the technology development interface [18]. It is notable that the same constraints are used in measuring competitiveness making a strong link between total factor productivity and competitiveness [19]. It is evident that by increasing total factor productivity, a company can expect more output [18]. Despite productivity being a simple relationship ratio between input and output, most of the managers seldom measure in an appropriate way [20].The main cause of misunderstanding being the ambiguity surrounded around the productivity terminology [8]. In the academic literature, productivity is often discussed with in the scheme of things in a corporate strategy but due to the lack of a proper definition, managers start to measure productivity on their own terms and conditions [10]. The research literature indicates that four different terminologies are used for defining productivity: Profitability, Performance, Effectiveness and Efficiency $[21-26,8,20]$. It is evident that the concept of productivity has been in existence for a long period of time but people making decisions about plant or company productivity find it difficult to define a simple terminology of productivity"? [27]. A strategic perspective of productivity usually differs from the operational view of productivity, as a lack of awareness of multiple definitions and interpretations of productivity cause this distinctive view [8]. However, the definition of productivity has many similarities while productivity often relates to higher achievement in all fields of economics and engineering [28]. Despite the similar definitions of productivity, there are three different productivity categories [29]:

1. The technological definition of productivity being the relationship between ratios of output to the inputs in operations.

2. The engineering definition being the relationship between the actual and the forecasted output of an operation.

3. The economic definition being the efficiency coefficient of any resource allocation.

Productivity is still considered to be a relative concept as increased production does not correspond to an automatic increase in productivity and it cannot increase or decrease in its own, unless a comparison is made from a competitor's view or from another departmental perspective [8]. The improvements in productivity can be caused by five different relations highlighted in Table 1 [30]. The table indicates how productivity index is measured based on the input actions and the output derived. Despite this indicator, manufacturing organizations relate productivity to its physical phenomenon [31] classified as outputs from the manufacturing process, making the efficiency measurement of impossible.

Table 1: Measuring Productivity Index

\begin{tabular}{|l|l|l|}
\hline Input Actions & $\begin{array}{l}\text { Output } \\
\text { Changes }\end{array}$ & $\begin{array}{l}\text { Productivity } \\
\text { Index }\end{array}$ \\
\hline $\begin{array}{l}\text { Increase in } \\
\text { input }\end{array}$ & $\begin{array}{l}\text { Increase in } \\
\text { output }\end{array}$ & $\begin{array}{l}\text { "Managed" } \\
\text { Growth }\end{array}$ \\
\hline Same input & More output & "Smart" method \\
\hline $\begin{array}{l}\text { Reduction of } \\
\text { input }\end{array}$ & More output & The "ideal" index \\
\hline Fewer inputs & Same output & $\begin{array}{l}\text { "Higher" } \\
\text { efficiency }\end{array}$ \\
\hline $\begin{array}{l}\text { Input } \\
\text { decreases }\end{array}$ & $\begin{array}{l}\text { Output } \\
\text { decreases }\end{array}$ & \begin{tabular}{l} 
Decline \\
\hline
\end{tabular}
\end{tabular}

\subsection{Research Aims}

Productivity is often portrayed in conjunction with resources and closely related to value generation of a process [32]. The main drivers of productivity are linked to any government or company strategy and any policies that are structured by the government target these drivers, ensuring success of a company or a country. It is however essential to measure productivity in a strategic, tactical and an operational level in-line with the competitors to demonstrate progress on productivity growth. This research aims to define the terms of productivity in relationship to profitability, effectiveness, efficiency and performance and identify the main drivers of productivity that have an impact in UK's manufacturing strategy.

\subsection{Profitability}

The companies often ignore the importance of productivity because of assumption that profitability and productivity are the same [8]. It cannot be denied that profitability and productivity are interdependent, but both these aspects do not always get along together [33]. It is evident the predominant objective for any business in a market is profitability or generating economic wealth [34,35]. Profitability has three distinctive indicators [36]:

1) It is one of the main indicators for the business to survive in the market or stay in competition.

2) It is used as one of the main value for long term planning of any business.

3) It is used as a tool for adding new businesses.

All these indicators clearly point that profitability is seen as a mere economic value in most of the 
companies [37]. If a new product or service fails to earn profit, the company presumes that the team involved was not productive. The profitability is strongly attributed by the revenue stream of the company. If the company or business unit can price its output much higher than the competitor and manage to be successful in generating good revenue despite having lessinput cost, nullifies the productivity measures and still highlight profit. This is a case of many monopolist markets where the product makes a profit and productivity is not considered. In case of price inflation and depreciation the profitability of a company will affect and this has no correlation to productivity. In this context, researchers augment that productivity is more a suitable indicator to monitor manufacturing excellence in a longer teem as profits are influenced by revenue factors which are normally short term strategic activities of the company [24]. In Figure 2, it is illustrated that productivity is defined as output quantities (product) per input quantities (resource) and any change in resource quantity or product quantity will change the productivity. Profitability however, is defined as output quantities (revenue) per input quantities (cost). According to Miller [24], "Profitability $=$ Productivity + Price recovery" where price recovery is defined as output quantities product price per input quantity resource cost. It is therefore recommended for companies to combine profitability and productivity ratios so that the managers can monitor the valid reasons for any increased or decreased profits.

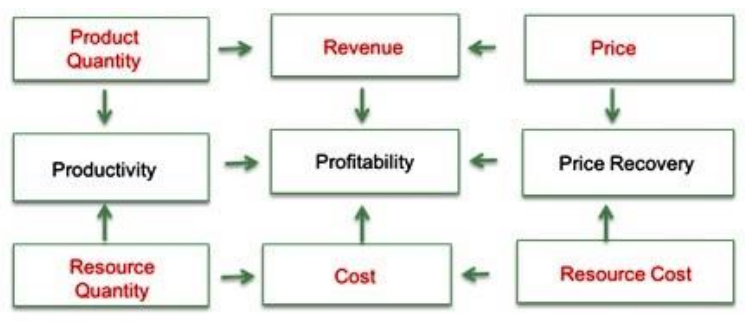

Figure 1: Profitability in relation to Productivity after Miller (1994)

\subsection{Performance}

The companies claiming to focus on productivity are actually looking on the issue of performance [38]. Sometimes, a special skill displayed with in a particular setup and capability is often linked to performance [39]. It was already discussed within this review that productivity is a concept connected to the ratio between output and input. However, performance is a terminology which is used in a broader perspective of economic and operational dimensions in a company. Performance is closely knitted to most of the objectives in a company's competitive and manufacturing excellence strategy in relation to its cost, speed, dependability, flexibility or quality as illustrated in
Figure 3 [40]. In operations management, performance plays a vital part in productivity enhancement. Operations that are deemed to be distinctive, optimize effort and time to minimize defects and reworking of steps already performed or undertaken [26]. Some operations that are fast in nature establish minimal inprocess inventory and significantly reduce departmental, managerial, legislative and supervisory overhead [41]. In cases of dependability and reliability led operations, on-time delivery is guaranteed by establishing minimized disruption. In the case of flexible operations, tasks can change or adapt quickly and the challenge to switch priorities and maintaining brakeless operations can have a large effect in productivity [1]. The quality of delivery is often highlighted for a productive product or service but there are different factors like speed, dependability, reliability, adaptability, distinctiveness and optimization which would affect the productivity of the chain [42]. Any unknown disruptions to production process like equipment breakdown and supply chain interruption caused due to material flow generally have an effect on productivity but this cannot be linked in to performance [43]. In highly dependable operations, a high contingency plan is set with redundant equipment, staff on hold adding extra cost of the system but cannot be compromised with the type of operations planned for the customer satisfaction. The overall measurability of productivity in a company, unit or department becomes extremely complex if all the above factors of performance is taken in account and the benefit of improvement becomes questionable with all these effects.

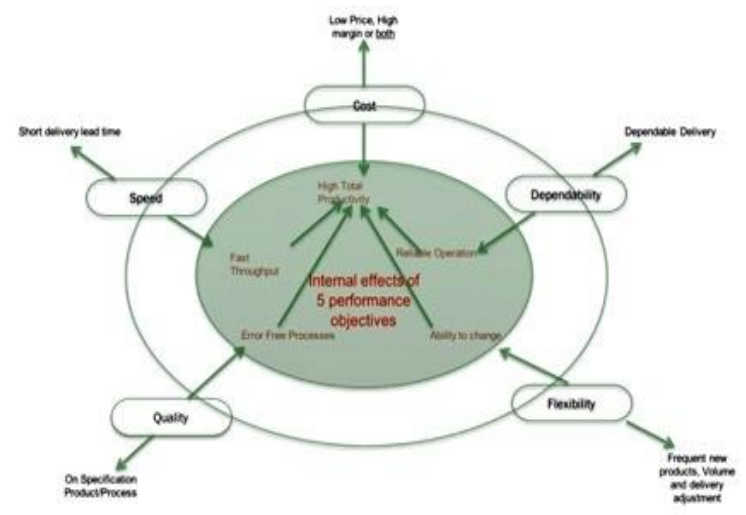

Figure 2: Performance in correlation to Competitive Priorities after (Slack, Chambers \& Johnston (2001)

\subsection{Effectiveness and Efficiency}

It is not only performance which often gets mixed up with productivity but also effectiveness and its relation to productivity $[44,45]$. While effectiveness is a 
definitely a closer kin to productivity but it is not without any confusion [46]. Organized developments in manufacturing fields are effortlessly claimed due to improved effectiveness [47]. Researchers claim that effectiveness is the main parameter to be considered in an organizational design [48]. The central theme of an organizational setup is focused around effectiveness [49]. Effectiveness is a pattern of performance where the right tasks are chosen at the right time, to create an expected outcome [9]. Effectiveness is often linked to creation of value in a process and it is something which is difficult to quantify, as it is an output oriented proposition [9] Effectiveness is measured with the accuracy of completeness on a scale of actual output by the expected output in terms with quality of the solution and the error rates [50]. While effectiveness is all about "doing the right things", efficiency is about "doing things right"[9]. Efficiency is linked to utilization of resource and its ratio can be measured on time and money [51]. The combination of higher values of both the efficiency and effectiveness in the process that leads to productivity [52]. The efficiency in manufacturing translates to utilization of minimum resource required to operate a system in comparison with the actual resources required to perform the system [8].

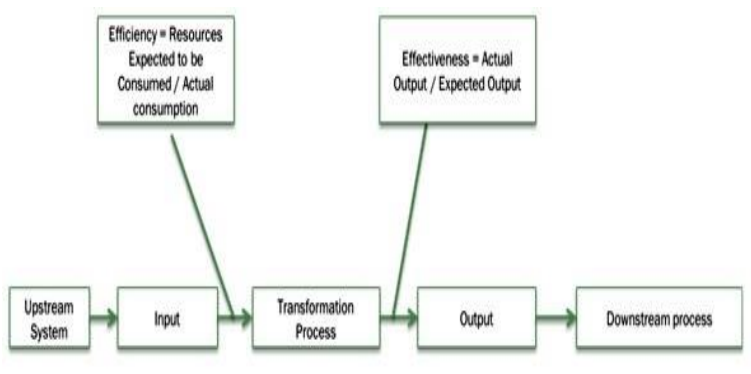

Figure 3: Effectiveness vs Efficiency (Sink \&Tuttle 1989)

2 Why is "Productivity" important topic for Manufacturing?

\subsection{Country level}

The majority of key decision makers in politics, academics and industries still are keen to compare the UK's productivity gap with the USA, Germany and France, despite the UK's far reaching economic reforms of the last two decades to overcome the individual competitiveness [53]. The UK is definitely in-line with all major nations that focus on performance and productivity by generating new reforms and policy to boost economic growth [54]. It is evident that productivity remained as an ambiguous concept despite widespread acceptance of its importance and Porter [55] validates this argument by claiming that a country's stand of living is directly determined with the productivity of its economy and till is related to this important attribute, productivity will remain as a hot topic. It is evident that a productivity driven economy is a platform where skilled workforce with high wages employment with a strong international currency to drive the market can achieve higher return of capital for investments and where the citizens such an economy enjoying a high standard of life [56].

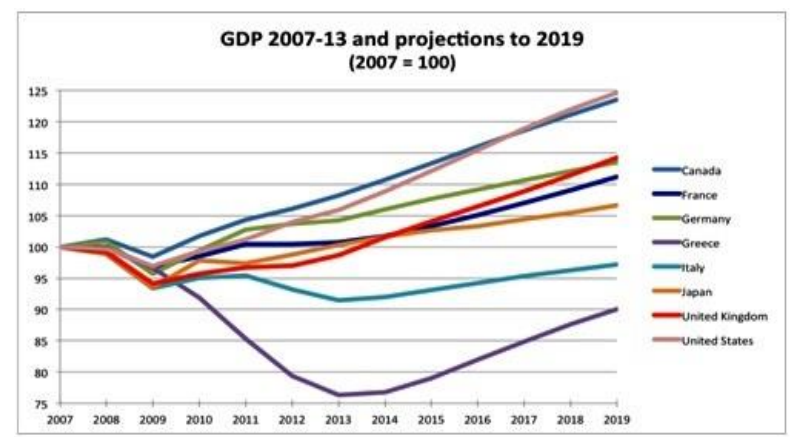

Figure 4: IMF Economic World Outlook

The UK's current economic performance in terms of GDP is on the upward scale as shown in Figure 5 when comparing to the pre-1980 period, where it lost its ground to all major economies [55]. The IMF's projection of GDP growth highlights a comparatively high growth rate in the coming years and indicates pockets of excellence in its productivity performance. Nevertheless, the UK is considered to be behind economies like Canada in labor productivity and will remain behind in the years to follow [57]. This proposed research underpins the manufacturing context of productivity as the manufacturing contribution to the UK economy has significantly changed over the last 60 years. Despite the economic down turns in 1970's to 1990's and the recent economic downturn in 2009, the manufacturing output in UK has grown to $1.4 \%$ [58].

As the labor and capital factor changes in the long term, the manufacturing output is bound to change in correspondence to increase or decrease. With any increase in labor and capital, the manufacturing output is increased. In-depth analysis of economic recessions have identified that jobs losses in majority of the industries was due to minimal capital inflow while the UK manufacturing output has remained steady as data indicates that the labor productivity measured by output per labor hour worked has actually increased with lower capital, enhancing the overall productivity [58]. This surprisingly indicates that the UK manufacturing industry is not in a decline and manufacturing productivity has been increased despite the decrease in capital. 


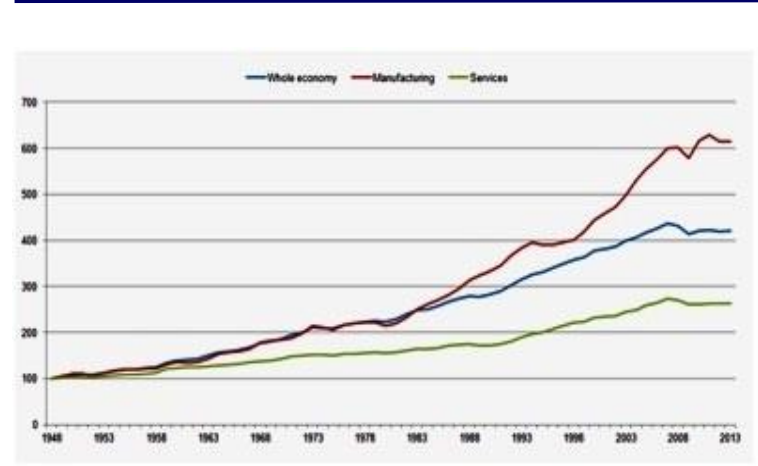

\section{Figure 5: Increase of Labor Productivity in the UK (Source adapted from UK office of National Statistics)}

The economic downturn in 2008 in Figure 6 indicates a sharp decline in labor productivity both in manufacturing and services but the productivity growth has consolidated in the recent past. Manufacturing productivity is still in the upwards trend in comparison to the service industry. The 2.8\% manufacturing growth compared to the $1.5 \%$ growth of the service industry in the pre-economic recession growth indicates that manufacturing productivity is definitely the winner in comparison to the economy as a whole [58]. On one hand, the labor productivity in manufacturing as shown in Figure 7 indicates slower output growth due to the job cuts. Whereas, the whole economy has shown signs of better growth with more labor input in comparison to manufacturing work force. Despite lower labor input in manufacturing and manufacturing being a labor intensive industry [59], the labor productivity growth on manufacturing with significantly less workforce has provided more output growth than other sectors in the economy competing with higher work force and capital [58]. In the recent years, UK outsourced the low technical manufacturing to developing economies around the world and with capital intensive measures, the UK manufacturing yielded more efficient production process. This labor shift, eventually changes the number of labor hours in the economic context within the industry and the capital input contribution to growth is slower but consistent. The success despite the lower inputs being personnel with skill, experience and high-tech infrastructure development in the UK, affecting positively the overall manufacturing output [58]. Despite positive indicators on labor productivity within manufacturing, there remains considerable uncertainty in the UK in hiring principles of skilled workforce on the whole economic scale [19]. As long as productivity remains the valid parameter to provide higher quality of life, productivity will still remain as a urgent topic to address [56]. UK is in the cross road of global trade, foreign investment and innovation. According to Porter "Productivity growth is underpinned with these factors of global attractiveness" [53].

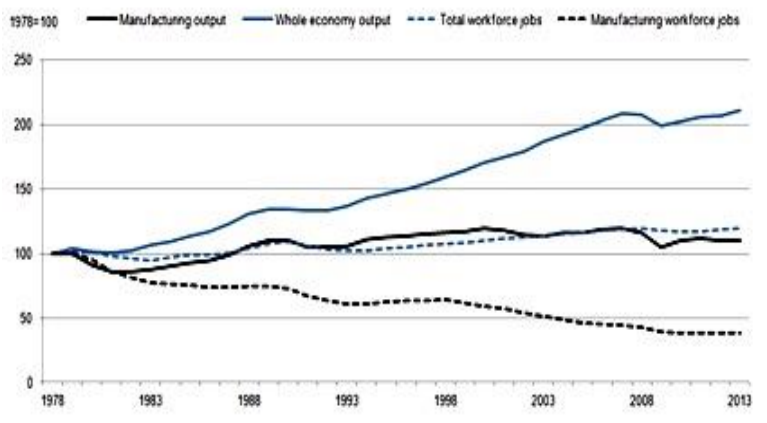

Figure 6: Productivity Growth vs Economic Growth (Source: Index of Production, GDP and Labor Market from the UK office of National Statistics)

\subsection{Firm level}

The companies focusing on manufacturing productivity mainly in automotive sectors place increasing emphasis on collaboration, network and supply chain management to gain competitive advantage in the market [60]. The traditional way of handling effective economic development in automotive companies was prioritizing productivity measures, by inclusion of best practices in the top of strategy and just focusing on performance of a single company or a single profit making department within the organization [53]. However, automotive manufacturing companies in Japan, strategically segmented suppliers for enhancing productivity in identifying supply chain best practices that aligned with people, processes and technology [61]. Many companies, opt a continuous improvement model to enhance their core performance and competitiveness using Supply Chain Management and most of the companies often do not succeed in maximizing their potential because of failure to develop performance measures and metrics that require integration of their supply chain to maximize effectiveness and efficiency [62]. For a balanced approach an integrated supply chain approach is required by companies recognizing the importance of not only the financial and nonfinancial performances of the firm, but also organizational measures along its whole supply chain including the suppliers. The performance measure and metrics of a company are often based on the context of supply chain activities namely: 1) Plan, 2) Source, 3) make/assemble and 4) delivery/customer [63,62]. Performance of any company can be evaluated only based on its planning, sourcing, making and delivery measures along the supply chain [64]. It is important to acknowledge that supply chain partnership is a collaborative relationship that requires 
interdependence from the buyer and seller and the productivity of the chain is determined by the measures that all the parties take in the chain to gain efficiency and effectiveness [65]. The successful companies in the domain of automotive and aerospace engineering adopted lean systems to facilitate production, transportation and even management of information [22]. Similarly, automotive manufacturing companies gained reputation for delivering high customer service level after adopting a dynamic customer service strategy [66]. The companies that evaluate their business operations based on the context of supply chain efficiency, flow, responsiveness and customer satisfaction have successfully increased confidence among the investors or share holders and have enhanced production with efficient utilization of resources, increasing the overall productivity of the company and its supply chain partners [67]. The manufacturing companies have recognized productivity to be much more important than profits or the revenues generated while increased efficiency and effectiveness of business generates the required profit or revenue on its own and in addition provides higher customer levels of customer service gaining a competitive advantage.

\section{Key drivers for enhancing productivity}

As it is evident that productivity is a paramount indicator of economic growth and living standards for companies and nations $[68,7,69]$, the British Treasury Department identified 5 key drivers that enhance the productivity of a company or a nation $[70,71]$. The key drivers are (1) Investment (2) Innovation (3) Enterprise (4) Competition and (5) Skills:

Investments: Productivity is often linked to investments and most of the companies firmly believe in increasing investments in the area of automation to facilitate production units, providing more product outputs with limited resources [2], presuming higher overall growth. Investments require resources, capital and equity. Investments are time dependent and payoff its dividend only in a longer time frame.

Innovation: Innovation can be simple yet effective. It is culmination of new ideas, methods, best practices and revolutionary thinking $[70,72,54]$. Innovation can be induced in any stage of the product development and its purpose not limited only to the technical aspects of the process but supports on business model creation, management practices, and marketing or new servitization principles [73].

Enterprise: An enterprise creates a conducive platform for business to innovate and adopt changes that are required to compete in a global market [74].
Without this essential parameter, productivity cannot be tested.

1) Competition: In the absence of competition, there is no necessity to innovate and grow $[54,75]$. The effect of competition is mainly allowing the companies to grow and providing incentives to improve performance [5].

2) Skills: In order to innovate and open the door for an healthy investment, the enterprise must possess skilled workforce fulfilling the criteria set by customers with the stipulated amount of time, resources required and higher value than the competitors [76]. The industry is deemed productive, if skills of diverse experience combines with skills required for performing a task which is highly innovative in nature $[77,78]$.

Table 2: Key Drivers of Productivity

\begin{tabular}{|c|c|c|c|}
\hline $\begin{array}{l}\text { Key } \\
\text { Drivers }\end{array}$ & Effects & Resources & Time \\
\hline 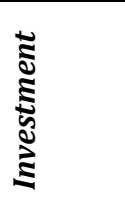 & $\begin{array}{l}\text { Facilitate } \\
\text { production, } \\
\text { Employ staff, } \\
\text { Acquire new } \\
\text { facilities }\end{array}$ & $\begin{array}{l}\text { Capital, } \\
\text { equity, loans }\end{array}$ & $\begin{array}{l}\text { Mid- } \\
\text { long }\end{array}$ \\
\hline 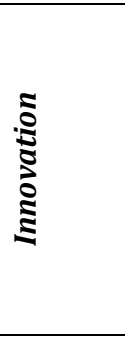 & $\begin{array}{l}\text { Facilitate } \\
\text { production, } \\
\text { create new } \\
\text { processes, create } \\
\text { best practices, } \\
\text { time } \\
\text { management, } \\
\text { quality } \\
\text { management }\end{array}$ & $\begin{array}{l}\text { Ideas, } \\
\text { Mobility, }\end{array}$ & $\begin{array}{l}\text { Short- } \\
\text { mid }\end{array}$ \\
\hline 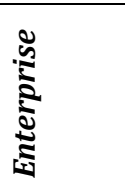 & $\begin{array}{l}\text { Creation of a } \\
\text { conducive } \\
\text { environment }\end{array}$ & $\begin{array}{l}\text { People, } \\
\text { Quality } \\
\text { Management }\end{array}$ & $\begin{array}{l}\text { Short- } \\
\text { mid- } \\
\text { long }\end{array}$ \\
\hline 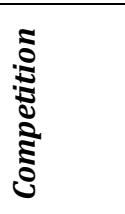 & $\begin{array}{l}\text { Platform for } \\
\text { growth }\end{array}$ & $\begin{array}{l}\text { Business } \\
\text { model }\end{array}$ & $\begin{array}{l}\text { Mid- } \\
\text { long }\end{array}$ \\
\hline$\underset{\pi}{\tilde{s}}$ & $\begin{array}{l}\text { Platform for } \\
\text { growth, platform } \\
\text { for innovation, } \\
\text { foster new } \\
\text { techniques and } \\
\text { processes for } \\
\text { business } \\
\text { facilitation }\end{array}$ & $\begin{array}{l}\text { People, } \\
\text { Experience }\end{array}$ & $\begin{array}{l}\text { Short- } \\
\text { mid }\end{array}$ \\
\hline
\end{tabular}


According to the Automotive Council of UK, the automotive sector employees in Britain deliver higher added value (over $100 \mathrm{~K}$ Euros/year) in comparison to other leading global automotive companies including Germany which is placed only in the second after UK.

The UK economy has seen a strong comeback in manufacturing productivity in comparison to the whole economic growth, despite job cuts in manufacturing. This is due to the increase in better skilled workforce, enhanced IT infrastructure in manufacturing, commitment and access to better research and development funding, strong measures to deepen the capital and overall an integrated global economic policy. Productivity is closely connected to manufacturing and several factors like quality, delivery, costs and flexibility are still vital in facilitating growth of a company. In order to enhance productivity in manufacturing a supply chain management measure is required mainly in planning, sourcing, making and in delivery. The metrics and measures required in enhancing productivity in the context of a supply chain management perspective are classified as:

1) Strategic level measure that focusses on reducing lead-time, increasing quality and saving costs.

2) Tactical level measures that optimize efficiently the order cycle time, booking-in procedures, methods for assuring quality and allowing capacity flexibility.

3) Operational level measures that evaluate the supply link, the customer order log, planning and scheduling of orders, track complaints and minimize defects.

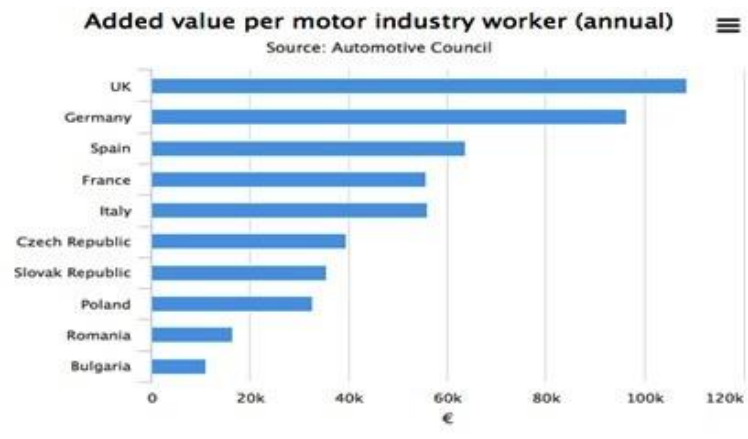

Figure 7: UK's higher productivity growth in Automotive Sector (Source: Automotive Council, UK)

\section{CONCLUSION}

The manufacturing productivity strategy must be based on an effective supply chain management principle ensuring materials arrive on time, in full, at the correct production sites without halting any production. Any such delays will cause the workers to be inactive adding unnecessary costs, in addition to the company failing to fulfill orders on a specific time resulting in poor customer service. The concept of enhancing productivity by accurately planning procurement and production based on consumer demands can avoid excessive inventory or manufacturing over-runs reducing significant costs and at the same time improving customer service levels.

\section{REFERENCES}

[1] Tangen, S., 2004. Performance measurement: from philosophy to practice. International Journal of Productivity and Performance Management, 53(8), 726-737.

[2] Coelli, T.J. 1996. Measurement of total factor productivity growth and biases in technological change in Western Australian agriculture. Journal of Applied Econometrics, 11(1), 77-91

[3] Rao, D.P., Battese, G.E. 1998. An introduction to efficiency and productivity analysis. Boston: Kluwer Academic Publishers.

[4] Wazed, M., Ahmed, S. 2008. Multifactor Productivity Measurements Model (MFPMM) as Effectual Performance Measures in Manufacturing. Australian Journal of Basic and Applied Sciences, 2(4), 987-996.

[5] Camus, D. 2007. The ONS Productivity Handbook: A statistical overview and guide, Office of National Statistics (UK), Hampshire.

[6] Cook, W.D., Zhu, J. 2007. Classifying inputs and outputs in data envelopment analysis. European Journal of Operational Research, 180(2) 692-699.

[7] Singh, H., Motwani, J., Kumar, A., 2000. A review and analysis of the state-of-the-art research on productivity measurement. Industrial Management \& Data Systems, 100(5) 234-241.

[8] Tangen, S. 2005. Demystifying productivity and performance. International Journal of Productivity and Performance Management, 54(1) 34-46.

[9] Sink, D. Scott, S. J. DeVries, and T.T. 1984. "An In-depth Study and Review of State-ofthe-art and Practice of Productivity Measurement Techniques." Proceedings of May 1984 Annual Conference, Institute of Industrial Engineers.

[10] Kinnander, A. and P.G. 1999. Productivity development in manufacturing systems-a project proposal within PROPER.,

[11] Samuelson, P.A. 1999. Samuelson's "Economics" at Fifty: Remarks on the 
Occasion of the Anniversary of Publication. The Journal of Economic Education, 30(4), 352-363.

[12] Freeman, R. 2008. Labour Productivity Indicators - Comparison of Two OECD Databases, Productivity Differentials and The Balassa-Samuelson Effect. Statistics, (July), p.76

[13] Comin, D., 2006. Total Factor Productivity. Journal of the American Dietetic Association, 91(9) 1088-92.

[14] Sargent, T.C., Rodriguez, E.R. 2000. Labour or Total Factor Productivity: Do We Need to Choose? International Productivity Monitor, 1(August) 41-44.

[15] Baumol, W.J. 1986. Productivity Growth, Convergence, and Welfare: What the Longrun Data Show. American Economic Review, 76(5) 1072-85.

[16] Hong, B., 2008. Cobb-Douglas Production Function. Discovery, pp.1-7.

[17] Crafts, N., 2001. Performance. , 22(3), pp.271-306.

[18] Groth, C., Gutierrez-Domenech, M., Srinivasan, S., 2004. Measuring total factor productivity for the United Kingdom. Bank of England Quarterly Bulletin, (Spring), pp.63-73.

[19] Barnett, A. 2014. The $\{U K\}$ Productivity Puzzle. Bank of England Quarterly Bulletin, 54(2) 114-128.

[20] Koss, Ellee, and D.A.L. 1993. "Productivity or efficiency-Measuring what we really want." National Productivity Review 12.2, p.273-284.

[21] Anderson, E.W., Fornell, C., Rust, R.T., 1997. Customer satisfaction, productivity, and profitability: Differences between goods and services. Marketing Science, 16,129-145.

[22] Anderson.1996. Customer Satisfaction Productivity and Profitability differences between Goods And Services.

[23] Forrester, J.W., 1993. Low productivity: it is a problem or merely a symptom?." Handbook for Productivity. Handbook for Productivity Measurement and Improvement, Productivity Press, Cambridge, MA.

[24] Miller, D.M., 1984. Profitability = Productivity + Price Recovery. Harward Business Review, May-June, pp 145-153,.

[25] Sink, D.S., 1991. The role of measurement in achieving world-class quality and productivity management. Industrial Engineering, 23(6) 23-9.

[26] Slack, N. 2012. Operations and Process Management. Operations Management, p.760.
[27] Chew, W.B., 1988. No-Nonsense Guide to Measuring Productivity. Harvard Business Review, 66(1), pp.110-115.

[28] Broman, M., 2004. "Assessing productivity in assembly systems." Licentiate thesis, Department of Production Engineering, The Royal Institute of Technology, Stockholm.

[29] Ghobadian, Abby, and T.H., 1990. Measuring total productivity using production functions. The International Journal of Production Research, 28.8, p1435-1446.

[30] Misterek, S.D.A., Dooley, K.J. \& Anderson, J.C., 1992. Productivity as a Performance Measure. International Journal of Operations \& Production Management, 12(1) 29

[31] Golden, L. 2011. The effects of working time on productivity and firm performance: a research synthesis paper. Conditions of Work and Employment Series, (33), pp.134.

[32] Slack, N.2005. Operations strategy: will it ever realize its potential? Gestão \& Produção, 12, 323-332.

[33] West, 1999. "Essays on productivity, flexibility, and manufacturing networks", Thesis No. 757, Department of Production Economics, Linkoping University, Linkoping.Automotive Council of UK (www.automotivecouncil.co.uk)

[34] Felton, A.P. 1959. Making the Marketing Concept Work. Havard Business Review, 37(4), pp.55-65.

[35] McNamara, C.P., 1972. The Present Status of the Marketing Concept. Journal of Marketing, 36, 50-57.

[36] Kohli, A. K., Jaworski, B.J., Kumar, a. 1993. MARKOR: Measure of Market Orientation. Journal of Marketing Research, 30(4), pp.467-478.

[37] Narver, J.C., Slater, S.F. 1990. The Effect of a Market Orientation on Business Profitability. Journal of Marketing, 54(October), 20-35.

[38] Thomas, B. and Baron, J., 1994. Evaluating Knowledge Worker Productivity: Literature Review, USACERL Interim Report FF-94/27, USACERL, Champaign, IL.

[39] Stainer, A., Nixon, B., 1997. Productivity and performance measurement in R\&D. International Journal of Technology Management, 13, 486-496.

[40] Slack, Nigel, Stuart Chambers, R.J. 2001. Operations management. Pearson education,

[41] Slack, N., Lewis, M., Bates, H. 2004. The two worlds of operations management research 
and practice: Can they meet, should they meet? International Journal of Operations \& Production Management, 24(4) 372-387.

[42] Boyer, K.K., Lewis, M.W. 2002. Competitive priorities: Investigating the need for tradeoffs in operations strategy. Production and Operations Management, 11(1) 9-20.

[43] Macduffie, J.P. 1995. Human Resource Bundles and Manufacturing Performance: Organizational Logic and Flexible Production Systems in the World Auto Industry. Industrial \& Labor Relations Review, 48(2) 197-221.

[44] Cameron, K. 2014. Construct Space and Subjectivity Problems in Organizational Effectiveness. Public Productivity Review, 5(2) 105-121.

[45] Mowday, R.T., Steers, R.M., Porter, L.W., 1979. The measurement of organizational commitment. Journal of Vocational Behavior, 14(2) 224-247.

[46] Quinn, R.E., Rohrbaugh, J.1983. A Spatial Model of Effectiveness Criteria. Management Science, 29(3) 363-377.

[47] French, Wendell L., C. H. Bell, Veena Vohra. 1989. "Organization Development: Theory." Practices And Research. Universal Book Stall New Delhi 17.

[48] Waldo, D., Jaques, E., Kilman, R.H., Pondy, L.R., Slevin, D.P., Kilman, R.H., Pondy, L.R., Slevin, D.P., Melcher, A.J., Meltzer, H. and Wickert, F.R., 1978. Organization theory: Revisiting the elephant.

[49] Goodman, Paul S., and J.M.P. 1977. New perspectives on organizational effectiveness. San Francisco: Jossey-Bass, 1977.

[50] Frøkjær, E., Hertzum, M., Hornbæk, K., 2000. Measuring Usability: Are Effectiveness, Efficiency, and Satisfaction Really Correlated? ACM CHI 2000 Conference on Human Factors in Computing Systems, 2(1) 345-352.

[51] Bevan, N., 1995. Measuring usability as quality of use. Software Quality Journal, 4(2), pp.115-130.

[52] Bailey, R.W., 1993. Performance vs. preference. In Proceedings of the Human Factors and Ergonomics Society 37th Annual Meeting. pp. 282-286.

[53] Porter,M., Ketels, C. 2003. UK Competitiveness : moving to the next stage. DTI Economics Paper, (3), p.URN 03/899.

[54] Bloom, N. \& Reenen, J. Van, 2006. Measuring and Explaining Management Practices Across Firms and Countries. Journal of Chemical Information and Modeling, 53, 1689-1699.
[55] Porter, M., 2002. Enhancing the Microeconomic Foundations of Prosperity: The Current Competitiveness Index. The global competitiveness report. Geneva: World Economic forum, pp.52-76.

[56] Porter, M.E., Schwab, K., 2009. The Global Competitiveness Report 2008 - 2009,

[57] Baldwin, J., Yan, B., 2014. Global Value Chains and the Productivity of Canadian Manufacturing Firms., Economic Analysis Research Paper Series, Statistics Canada Catalogue no.11F0027M, no. 090.

[58] Hardie, M., Banks, A., 2014. The Changing Shape of UK Manufacturing. Office for National Statistics, (October), pp.1-20.

[59] Kaplinsky, R., Morris, M. 2002. A Handbook for Value Chain Research. , (September).

[60] McLaughlin, P., 2013. Manufacturing best practice and UK productivity. , pp.1-54.

[61] Dyer, J.H., Ouchi, W.G., 1993. Japanese-Style Partnerships Giving Companies a Competitive Edge. Sloan Management Review, 35, 51-64.

[62] Gunasekaran, A., Patel, C., McGaughey, R.E. 2004. A framework for supply chain performance measurement. International Journal of Production Economics, 87(3),

[63] Stewart, G. 1995. Supply chain performance benchmarking study reveals keys to supply chain excellence. Logistics Information Management, 8(2) 38

[64] Macbeth, D.K., Ferguson, N.1993. Strategic Aspects of Supply Chain Management. Integrated Manufacturing Systems, 2(1) 812

[65] Cooper, Martha C., L.M.E. 1993. Characteristics of supply chain management and the implications for purchasing and logistics strategy. The International Journal of Logistics Management 4.2, 13-24.

[66] Griffin-Cryan, B. 2011. Lean in Supply Chain Planning. , pp.1-16.

[67] Heikkilä, J., 2002. From supply to demand chain management: efficiency and customer satisfaction. Journal of operations management 20.6 747-767.

[68] Gretton, Paul, B.F., 1997. Productivity growth and Australian manufacturing industry. Australia: Industry Commission.

[69] Schreyer, P. \& Pilat, D., 2001. Measuring Productivty, Paul Schreyer and Dirk Pilat. OECD Economic Studies, (33) 127-170.

[70] Agarwal, R., Selen, W. 2011. Multidimensional nature of service innovation: Operationalisation of the elevated service offerings construct in collaborative service organisations. International Journal of Operations \& Production 
Management,31(11) 1164-1192.

[71] Gunsalus, J. 2009. Boeing sticks to revised 787 Dreamliner schedule. Bloomberg Press.

[72] Love, J.H., Mansury, M.A., 2007. External linkages, R\&D and innovation performance in US business services. Industry \& Innovation, 14(5) 477-496

[73] Potts, J. 2009. Why creative industries matter to economic evolution. Economics of Innovation and New Technology, 18(7) 663-673.

[74] Romero-Martinez, A.M., Montoro-Sanchez. 2008. How clusters can encourage entrepreneurship and venture creation. Reasons and advantages. International Entrepreneurship and Management Journal, 4(3) 315-329.
[75] Dong, S., Xu, S.X., Zhu, K.X., 2009. Information technology in supply chains: The value of IT-enabled resources under competition. Information Systems Research, 20(1) 18-32

[76] Oldham, G.R., Hackman, J.R. 1981. Alternative Frameworks Relationships Between Organizational Structure and Employee Reac- tions: Comparing Alternative Frameworks Greg R. Oldham and. Administrative Science Quarterly, 26(1) 6683.

[77] Lusch, R.F., Vargo, S.L., Tanniru, M. 2009. Service, value networks and learning. Journal of the Academy of Marketing Science, 38(1) 19-31

[78] Sampson, S.E., Froehle, C. 2006. Foundations and Implications of a Proposed Unified Services Theory. Handbook of service science, 15(2) 329-343.

All (c) 2020 are reserved by International Journal of Advanced Science and Engineering. This Journal is licensed under a Creative Commons Attribution-Non Commercial-ShareAlike 3.0 Unported License. 